\title{
Laboratory Tests of Substrate Physical Properties May Not Represent the Retention Capacity of Green Roof Substrates In Situ
}

\author{
Christopher Szota ${ }^{1, *}$, Tim D. Fletcher ${ }^{1}$, Carine Desbois ${ }^{1,2}$, John P. Rayner ${ }^{1}$, \\ Nicholas S. G. Williams ${ }^{1}$ and Claire Farrell ${ }^{1}$ \\ 1 School of Ecosystem and Forest Sciences, The University of Melbourne, 500 Yarra Boulevard, \\ Richmond 3121, Victoria, Australia; timf@unimelb.edu.au (T.D.F.); carine.desbois@gmail.com (C.D.); \\ jrayner@unimelb.edu.au (J.P.R.); nsw@unimelb.edu.au (N.S.G.W.); c.farrell@unimelb.edu.au (C.F.) \\ 2 INSA Lyon, 34 Avenue des Arts, 69621 Villeurbanne CEDEX, France \\ * Correspondence: cszota@unimelb.edu.au; Tel.: +61-3-9035-6919
}

Received: 29 September 2017; Accepted: 23 November 2017; Published: 27 November 2017

\begin{abstract}
Green roofs can be used to reduce the volume of polluted stormwater that is generated by cities. Modelling rainfall retention is critical, but green roof water balance models often rely on the physical properties of substrates. In these models, substrate water holding capacity (WHC) determines the depth of water which can be stored before runoff is generated; whereas, the permanent wilting point $(P W P)$ limits evapotranspiration. The $W H C$ and $P W P$, as well as plant available water $(P A W$; where $P A W=W H C-P W P)$, as determined from laboratory tests, may not truly reflect how substrates perform on green roofs. We therefore ran a simulated rainfall experiment on green roof modules to (i) compare the rainfall retention of vegetated and non-vegetated substrates with different $W H C$ and $P A W$, and (ii) relate retention to substrate storage capacity, as calculated from laboratory measures of WHC and $P A W$. We found that the $P A W$ of a substrate is a better indicator of evapotranspiration and retention when compared with WHC. However, we also found that substrates always retained less water than their calculated storage capacity would suggest, most likely being due to their high permeability. Our results indicate that using laboratory-derived measures of WHC and $P A W$ in green roof models may be over-estimating both evapotranspiration and rainfall retention.
\end{abstract}

Keywords: green roof; rainfall retention; water holding capacity; plant available water; succulent; rainfall simulation

\section{Introduction}

Creating impervious surfaces during urbanisation generates stormwater runoff [1], which is conveyed to urban streams by drainage networks that are designed to minimise flooding. Both the quality and the quantity of runoff degrade urban stream ecosystems [2-4]. A range of stormwater control measures, such as green roofs, wetlands, raingardens and swales, can be used to reduce these impacts by delivering more natural flow and water quality regimes [5].

Given that rooftops account for $30-50 \%$ of urban impervious surfaces [6,7], green roofs can make a significant contribution to reducing stormwater runoff volumes, frequencies, and flow rates [8]. Green roofs can occupy $100 \%$ of their impervious catchment area, making them particularly effective in retaining rainfall. These hydrological benefits have led to green roofs being increasingly adopted, with many cities legislating or encouraging their uptake [9].

The profile of a green roof typically contains a drainage layer, which is overlaid by a substrate layer that provides water and nutrients for plants. Most green roof substrates are made of lightweight, but stable inorganic or mineral components, with high porosity for drainage and up to $20 \%$ organic 
matter to aid water and nutrient supply [10-12]. The mineral components can include volcanic materials (e.g., scoria or lava rock) or expanded clays, as well as recycled building materials, including: crushed brick, roof-tiles, and concrete $[10,13]$. New green roof substrates are continually being developed from locally available materials [14,15]. Consequently, it is becoming more important to understand how substrate properties influence rainfall retention.

The long-term hydrological performance of a green roof depends on the amount of evapotranspiration $(E T)$, which in turn depends on both the vegetation type and the capacity of the substrate to store and supply water to the plants. Rainfall retention is therefore greatly influenced by substrate depth and physical properties, such as water holding capacity (WHC at field capacity) and air-filled porosity $(A F P)[8,16]$. For rainfall retention, deeper substrates with a greater WHC are optimal [8,16], but weight restrictions on supporting buildings mean that substrates are often shallow ( $<20 \mathrm{~cm}$ deep), and water retention is often compromised to achieve free drainage (i.e., a higher $A F P)$ [17]. It is also important to note that not all of the water retained by substrates is available for plant uptake [18]. Relying on WHC instead of plant available water (PAW) can thus potentially overestimate both water availability to plants and rainfall retention $[14,19]$. PAW represents the water held between WHC and permanent wilting point ( $P W P$; the water content beyond which plants can no longer extract water from the substrate).

Many experimental studies investigating runoff from green roofs have focused on the performance of proprietary substrates (see the review of [8]), with little reporting of their properties [20,21]. For example, $P A W$ is seldom measured (for exceptions see $[14,18,22,23]$ ), and is generally not supplied for commercially available substrates [24]. Yet, $P A W$ is potentially a more important predictor of green roof hydrologic performance than WHC [14]. Therefore, it is important to understand whether relying simply on $W H C$, and not considering PAW, will overestimate rainfall retention [14,23,25].

Limited knowledge of how green roof substrate properties influence retention makes it difficult to predict the hydrological performance of new green roof configurations. Modelling approaches have been proposed [26,27] to overcome this impediment, but their success depends on the accurate and realistic representations of in situ substrate water retention [24,27]. Some physical green roof hydrological models assume that the maximum rainfall retention capacity of substrates is equal to laboratory-based assessments of WHC or PAW [26,28-30]. However, laboratory-based assessments of WHC and PAW may not accurately reflect rainfall retention capacity of substrates in situ [14,23]. For example, when Versini et al. [31] developed a green roof model in SWMM, based on data from an experimental green roof, the optimal calibration of the WHC parameter in the model was around half the value determined by laboratory testing of the substrate. Such differences between actual rainfall retention and retention calculated from substrate properties have been attributed to preferential flow paths and high porosity/drainage rates [14,28,32], which can prevent green roof substrates from filling to their WHC, as determined in the laboratory.

To overcome this, most models set maximum storage as determined directly from experiments with green roof modules or full-size monitored roofs $[26,33,34]$. In a developing green roof industry, where novel drainage layers and substrates are continuously being developed, it is unlikely that all configurations will be evaluated experimentally. Although the storage capacity of components, such as drainage layers, can be determined with confidence, the maximum storage capacity of substrates in situ is difficult to predict from laboratory-based methods. Policy makers therefore need a method to accurately predict green roof performance prior to construction $[16,24]$. In the absence of such a method, assumptions are likely to be made about rainfall retention based on laboratory-determined substrate physical properties, such as $P A W$ and $W H C$, resulting in an over-estimation of rainfall retention performance.

In this study, we used a simulated rainfall experiment to: (i) determine how substrate physical properties and vegetation cover affect rainfall retention, and (ii) compare the in situ rainfall retention of green roof substrates with that predicted from their physical properties. We aimed to better predict rainfall retention from laboratory-derived substrate physical properties. 


\section{Materials and Methods}

\subsection{Experimental Design}

A simulated rainfall experiment was conducted over 89 days (9 August to 3 November 2011) in a rain-out shelter at The University of Melbourne's Burnley campus, Melbourne, Australia $(-37.828472,145.020883)$. We measured applied rainfall, retention, and runoff from simulated rain events to close the mass balance. Daily reference evapotranspiration $\left(E T_{0}\right.$; calculated as per Allen et al. [35]; Figure 1) was derived from patched-point SILO data [36] for the Melbourne Regional Office (site 086071; Australian Bureau of Meteorology, $3 \mathrm{~km}$ from the study location).

We used a factorial randomised block design with (i) substrate and (ii) vegetation cover (bare or planted) as treatments. Eighteen modules (3 substrates $\times 2$ vegetation treatments (bare and planted) $\times 3$ replicates) were constructed from $6 \mathrm{~mm}$ high density polyethylene plastic $(1160 \mathrm{~mm} \times 1160 \mathrm{~mm} \times 170 \mathrm{~mm})$ and supported by a steel frame on a plastic base at a $2^{\circ}$ slope. (Figure S1). The tray had a drainage layer (VersiDrain ${ }^{\circledR} 25 \mathrm{P}$, Elmich, Newington, NSW, Australia) overlain by geotextile fabric (Bidim ${ }^{\circledR}$ A14G, Geofabrics Australia PTY LTD, Melbourne, VIC, Australia) and $100 \mathrm{~mm}$ of the specified substrate.

The three substrates that were used in this experiment all had a mineral component $(80 \%$ by volume) of either: scoria (highly porous and vesicular volcanic rock, also referred to as lava rock or tuff), crushed terracotta roof-tile or black coal power station bottom-ash ('Envir-O-Agg', Boral, Sydney, Australia). The remainder ( $20 \%$ by volume) of each substrate was made up of horticultural grade coir [37]. Substrate water holding capacity (WHC) and air-filled porosity (AFP) were determined in test rigs that were composed of a top and base section, as per the Australian Standard AS 3743-2003 [38]. The base was made of a $120 \mathrm{~mm}$ long section of $90 \mathrm{~mm}$ diameter PVC (Polyvinyl Chloride) pipe, fitted with an end cap with four $10 \mathrm{~mm}$ holes drilled in the base for drainage. To create a standard level of substrate compaction in this base section, a section of $90 \mathrm{~mm}$ PVC pipe was fitted above the base, such that the total rig height was $240 \mathrm{~mm}$ ). The rig was filled with substrate, and then dropped onto a solid surface five times from a height of $50 \mathrm{~mm}$, such that the substrate in the top section provided a standard compaction force to the substrate in the base. This level of compaction is lower than that used in the FLL (Forschungsgesellschaft Landschaftsentwicklung Landschaftsbau) method [12], often used to assess green roof substrates and likely provides a more conservative estimate of WHC by maintaining macropores in the substrate. The top section was then removed and the surface of the substrate was made level with the top of the base section. The base section was then immersed in water (water surface level with the substrate surface) for $30 \mathrm{~min}$, and then drained for $5 \mathrm{~min}$, for three repeated cycles to ensure full saturation. After the third cycle, the mass of water draining from the substrate was determined and AFP (in \%), calculated by dividing the volume of drained water by the volume of substrate in the base section. The wet mass of the substrate was recorded, and then substrates were then oven-dried at $105^{\circ} \mathrm{C}$ for one week. WHC (in \%) was then calculated gravimetrically from wet and dry masses (Table 1$)$.

Plant available water (PAW) was determined using the filter paper method [39], adapted for green roof substrates, as described in Farrell, Ang and Rayner [22] and Cao, Farrell, Kristiansen and Rayner [18]. Each substrate was oven-dried at $105^{\circ} \mathrm{C}$ to a constant weight, then $20 \times 200 \mathrm{~g}$ samples of each were weighed out. Distilled water was added to each sample to bring them to between $5 \%$ and $100 \%$ of their WHC. Samples were transferred to glass jars with a filter paper (Whatman No. 42, Whatman plc, Maidstone, Kent, UK) inserted mid-sample. Jars were then sealed and left to equilibrate for one week. To give moisture release curves for each substrate, the gravimetric water content of the filter paper was then determined and the matric suction was calculated, as per Greacen, Walker and Cook [39]. The water content of each substrate at the permanent wilting point $(P W P ;-1.5 \mathrm{MPa})$ was derived from the moisture release curves and $P A W$ was determined by subtracting the $P W P$ from the WHC. 
The vegetated modules were planted on 25 February 2011, each with 24 plants, made up of six individuals of four succulent species: two exotic Sedum species (S. pachyphyllum Rose and S. clavatum Clausen) and two Australian native species (Carpobrotus modestus S.T. Blake and Disphyma crassifolium L.). The plants were tubestock (plugs of $50 \mathrm{~mm} \times 50 \mathrm{~mm} \times 125 \mathrm{~mm}$ ) and species were randomly allocated planting positions within each module. One month post-planting, $50 \mathrm{gm}^{-2}$ of slow release fertiliser (Osmocote ${ }^{\circledR}$ plus, Scotts Australia Pty Ltd, Sydney, Australia; 16 nitrogen (N):1.3 phosphorus (P):9.1 potassium $(\mathrm{K})$ ) was added to the surface of each module.
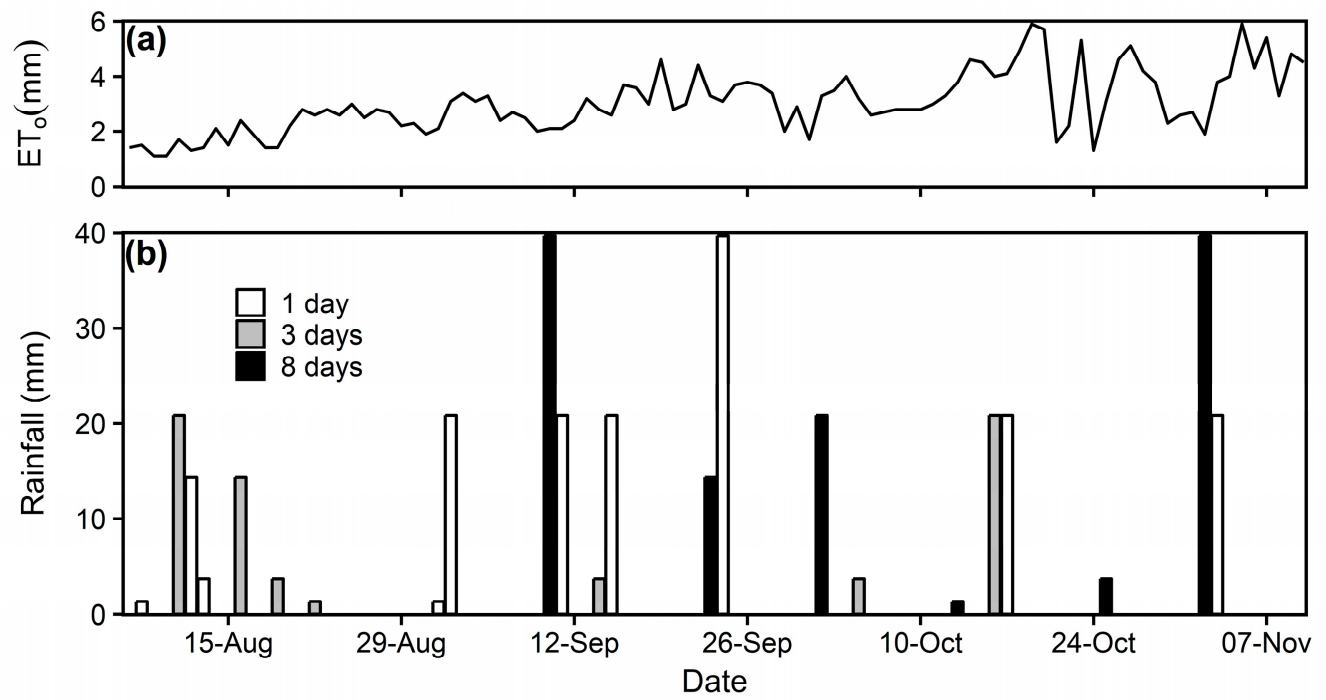

Figure 1. Summary of weather conditions during the experiment. (a) Daily reference evapotranspiration $\left(E T_{o}\right)$ for the experimental period and (b) frequency and size of simulated rainfall events, colour-coded by the number of antecedent dry days.

Table 1. Physical properties of the three green roof substrates evaluated, including: water holding capacity $(W H C)$, permanent wilting point $(P W P)$, plant available water $(P A W)$ and air-filled porosity $(A F P)$. Values (with standard error) represent the mean of 5 samples. Different letters indicate significant differences among substrates (one-way ANOVA). Values do not include drainage layer storage in modules.

\begin{tabular}{|c|c|c|c|c|}
\hline Substrate & $\begin{array}{c}\text { WHC } \\
(\%)\end{array}$ & $\begin{array}{c}P W P \\
(\%)\end{array}$ & $\begin{array}{c}P A W \\
(\%)\end{array}$ & $\begin{array}{c}A F P \\
(\%)\end{array}$ \\
\hline Bottom-ash & $51.7^{\mathrm{c}}$ & $6.46^{\mathrm{b}}$ & $45.2^{\mathrm{c}}$ & $13.8^{b}$ \\
\hline $60 \%<2 \mathrm{~mm}$ bayswater sand, $20 \%<10 \mathrm{~mm}$ eraring filter and $20 \%$ coir & $(0.4)$ & $(0.05)$ & $(0.3)$ & $(0.5)$ \\
\hline Roof-tile & $44.0^{\mathrm{a}}$ & $2.86^{\mathrm{a}}$ & $41.1^{\mathrm{b}}$ & $7.14^{\mathrm{a}}$ \\
\hline $80 \% 8 \mathrm{~mm}$ minus crushed roof tile and $20 \%$ coir & $(0.8)$ & $(0.01)$ & $(0.2)$ & $(0.3)$ \\
\hline Scoria & $45.9^{\mathrm{b}}$ & $8.72^{c}$ & $37.2^{\mathrm{a}}$ & $7.65^{\mathrm{a}}$ \\
\hline $60 \% 8 \mathrm{~mm}$ minus scoria, $20 \% 7 \mathrm{~mm}$ scoria and $20 \%$ coir & $(0.3)$ & $(0.06)$ & $(0.2)$ & $(0.6)$ \\
\hline
\end{tabular}

\subsection{Rainfall Simulation}

A clear plastic shelter ( $28 \mathrm{~m}$ long, $5 \mathrm{~m}$ wide and $2.5 \mathrm{~m}$ tall) with side openings to $0.9 \mathrm{~m}$ height and open ends was used to exclude natural rainfall from the modules (Figure S1). Rainfall was simulated by a pressure-regulated overhead irrigation system with a single row of dripless micro-sprinklers (Netafim SpinNet, Tel Aviv, Israel) spaced $0.68 \mathrm{~m}$ apart. Sprays were $1.32 \mathrm{~m}$ above the substrate surface (Figure S1), with an application rate of $28.2 \mathrm{~mm} \mathrm{~h}^{-1}$. Spatial variability of rainfall within each module was on average $\pm 3 \%$ of the rainfall depth applied (see Table 2). 
Table 2. Summary of the number of rain events applied and the length of antecedent dry weather periods (ADWP) applied in random order during the experiment. Error in rainfall depth (in $\mathrm{mm}$ ) associated with the irrigation setup is shown in parentheses below each rainfall event size.

\begin{tabular}{cccccccc}
\hline & & \multicolumn{7}{c}{ Event Size (mm) } & \\
\cline { 2 - 7 } Event Type & & $\mathbf{1 . 3 2}$ & $\mathbf{3 . 7 0}$ & $\mathbf{1 4 . 3 9}$ & $\mathbf{2 0 . 8 2}$ & $\mathbf{3 9 . 7 1}$ & Number of Events \\
& & $\mathbf{( 0 . 0 4 )}$ & $\mathbf{( 0 . 1 1 )}$ & $\mathbf{( 0 . 4 4 )}$ & $\mathbf{( 0 . 6 3 )}$ & $\mathbf{( 1 . 2 1 )}$ & \\
\hline \multirow{2}{*}{ ADWP (days) } & 3 & 1 & 3 & 1 & 2 & 0 & 10 \\
& 8 & 1 & 1 & 1 & 1 & 2 & 6 \\
\hline Number of events & 4 & 5 & 3 & 8 & 3 & 23 \\
\hline
\end{tabular}

Rainfall data (Melbourne Regional Office, station 086071) at a 6-min timestep for the period 1 January 1988 to 31 December 2007 were used to calculate statistics around daily rainfall depth $(\mathrm{mm})$ and antecedent dry weather period (days). The 10, 50, 90, 95, and 99 percentile daily rainfall depths were calculated $(1.32,3.70,14.39,20.82$, and $39.71 \mathrm{~mm})$, along with the 10, 50, and 90 percentile antecedent dry weather periods (i.e., the number of days without rainfall: 1, 3, and 8 days). We constructed a random sequence of events and dry weather periods to describe differences in retention among our treatments (Figure 1; Table 2). In total, we applied $352.6 \mathrm{~mm}$ of rainfall during the experiment.

\subsection{Runoff}

Runoff was collected and measured (by weight) $24 \mathrm{~h}$ after each simulated rainfall event from each module in two sealed buckets (volume $=25 \mathrm{~L}$, depth $=315 \mathrm{~mm}$ and height $=387 \mathrm{~mm}$; Figure S1). Water flowing out of each module was directed into the first bucket using PVC pipe (internal diameter $=86 \mathrm{~mm}$ ), and the two buckets were connected with a short length of PVC pipe (internal diameter $=43 \mathrm{~mm}$ ), acting as an overflow from the first bucket.

\subsection{Current Water Held in the System}

The combined weight of the empty module (tray, base, geotextile fabric, and drainage layer), substrate dry weight and plant biomass was subtracted from the total module weight at each beforeor after-event weighing to calculate the amount of water that was currently held by each module (Module Stor; see Equation (1) and Figure S2). Substrate dry weight was determined by oven drying $\left(105^{\circ} \mathrm{C}\right)$ two samples from each module at the end of the experiment to a constant weight. Plant fresh weight was measured at harvest (22 December 2011) and plant cover was measured three times during the experiment (5 September, 14 November and 22 December 2011), using the point intercept method [40]. Plant cover and biomass at harvest were not significantly different among substrates (mean cover 64.9\%, $p=0.52$; mean biomass $5.13 \mathrm{~kg}, p=0.07$ ). A linear relationship between cover and number of planted days was therefore used for all substrates to estimate plant weight for each day of the experiment. Although linear models of plant growth are a simplification of reality, it was consistent with the three point estimates of plant cover. Module storage was therefore calculated as:

$$
\text { Module Stor }=\frac{\text { Total }- \text { Plants }- \text { Module }- \text { Dry substrate }}{\text { Module area }}
$$

where Module Stor is the water currently stored in the system (including both the substrate and drainage layer; expressed in mm depth), Total is the total module mass (kg), Plants is the mass of the plants $(\mathrm{kg})$, Module is the mass of the module (including tray, base, geotextile fabric, and drainage layer; $\mathrm{kg})$, Dry substrate is the dry weight of the substrate $(\mathrm{kg})$, and Module area is the surface area of the module $\left(\mathrm{cm}^{2}\right)$. 


\subsection{Available Storage in the System}

We compared three methods of calculating available storage (Avail. Stor) of each green roof module before each event (see Figure S2). The three methods differed depending in the assumed

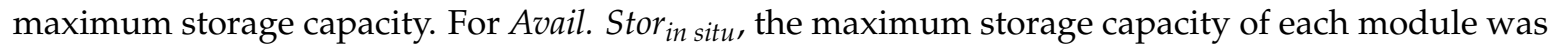
directly determined; i.e., equal to the measured field capacity of each module (Module FC). Module FC was directly determined for each module at the end of the experiment (using Equation (1)) after applying a very large rain event $(80 \mathrm{~mm})$, sufficient to thoroughly wet the system under the standard rainfall intensity. Avail. Stor ${ }_{P A W}$ and Avail. Stor ${ }_{W H C}$ were calculated by adding the maximum storage capacity of the drainage layer $(6.1 \mathrm{~mm})$ to the $P A W$ or $W H C$ for each substrate, as determined from laboratory tests (Substrate PAW and Substrate WHC); as shown in Table 1, converted from \% to depth in $\mathrm{mm}$. Available storage before each rain event was calculated by subtracting the current water stored in the system (Module Stor; from Equation (1)) from each method of determining maximum storage capacity, according to:

$$
\begin{aligned}
& \text { Avail. Stor } \text { in situ }=\text { Module FC }- \text { Module Stor } \\
& \text { Avail. Stor }{ }_{P A W}=\text { Substrate PAW }- \text { Module Stor } \\
& \text { Avail. Stor }{ }_{W H C}=\text { Substrate } W H C-\text { Module Stor }
\end{aligned}
$$

\subsection{Rainfall Retention}

Rainfall retention (Retention) for each event was determined as the difference between pre- and post- rainfall module weights (measured using a pallet-jack scale (TPS-1, T-Scale, Taiwan); accurate to $500 \mathrm{~g}$ ), with adjustment for ET on the day of the event (Equation (3)). Given the accuracy of the scale and the error associated with determining retention of the smallest event size $(1.32 \mathrm{~mm})$; only events of $>3.7 \mathrm{~mm}$ were included in our analysis; however, $1.32 \mathrm{~mm}$ events were still applied in the simulation (as per Figure 1).

For each simulated rain event, pre-rainfall module weights were captured early in the morning and post-rainfall weights $24 \mathrm{~h}$ later, to avoid affecting runoff capture by lifting the module. To determine retention, it was necessary to account for the loss of retained moisture via $E T$ in the hours following the simulated rain event $\left(E T_{\text {during }}\right.$ ). To estimate $E T_{\text {during, }}$, we adjusted $E T_{o}$ with a scaling factor ('SF'; 0.57 for vegetated and 0.48 for bare modules), as determined from between-event measures of $E T$ for each treatment (see Section 2.7). The scaling factors were thus determined by dividing the cumulative ET of each treatment by the cumulative $E T_{o}$ during the experimental period. $E T_{\text {during }}$ was considered to contribute to Retention, as calculated by weight change, as per:

$$
\text { Retention }=\text { Module Stor } r_{\text {after }}-\text { Module Stor }{ }_{\text {before }}+E T_{\text {during }}
$$

where Module Stor after $_{\text {and Module Stor }}$ before represent water storage in the module after and before the rainfall event (as per Equation (1)) and $E T_{\text {during }}$ is the $E T$ on the day of the rainfall event, with all of the units in $\mathrm{mm}$. We also calculated Cumulative Retention as the sum of Retention for all of the events, to compare the performance of substrates and vegetation cover types.

\subsection{Evapotranspiration betweeen Events and Cumulative Evapotranspiration}

Evapotranspiration between rain events $\left(E T_{\text {between }}\right)$ was directly determined from the difference in post-rainfall treatment module weight from the preceding event and weight measured immediately preceding the next rainfall event according to:

$$
E T_{\text {between }}=\text { Module Stor } \text { after event } n-\text { Module Stor }_{\text {before event } n+1}
$$

where $E T_{\text {between }}$ is the evapotranspiration (mm) between rainfall events $n$ and $n+1$, Module Stor after event $n$ and Module Stor before event $n+1_{1}$ are the total mass of the modules after event ' $n$ ' and before the next event 
$\left({ }^{\prime} n+1\right.$ '). Cumulative $E T$ was then calculated as the sum of $E T_{\text {between }}$ for all of the rainfall events over the experiment. Cumulative ET was used to relate substrate physical properties and vegetation cover to the total amount of $E T$ that was observed during the experiment.

\subsection{Data Analysis}

Statistical analyses were undertaken with R v. 3.0 .3 [41]. The effects of vegetation cover (planted vs. bare) and substrate type on Cumulative ET were analysed using two-way ANOVA for the entire experimental period. Significant differences among means were determined using Tukey's post-hoc test $(p<0.05)$. Statistical testing was undertaken after confirming populations that complied with the assumptions of normality of residuals and homogeneity of variance among groups.

Relationships between the three methods of calculating available storage (Avail. Stor in situ, $_{\text {, }}$ Avail. Stor ${ }_{P A W}$ and Avail. Stor $\left.{ }_{W H C}\right)$ and Retention were first determined for each substrate and vegetation cover type for each event size; then subsequently all substrate and vegetation cover types were pooled. As many of these relationships appeared to be non-linear, we fitted Multivariate Adaptive Regression Splines [42], or 'MARS' (Multivariate Adaptive Regression Splines) models; commonly referred to as 'broken-stick' models, using the 'earth' package [43]; see Section 3.2 for detail. Linear regression models were also fitted where appropriate. Prediction intervals (95\%) were estimated for each model as two times the residual standard error and goodness of fit (adjusted $R^{2}$ ), as determined from linear regression models of fitted versus observed values of Retention.

\section{Results}

\subsection{Influence of Substrate and Vegetation on Cumulative Evapotranspiration and Rainfall Retention}

Patterns in Cumulative ET and Cumulative Retention closely followed maximum storage as determined from $P A W$, rather than in situ or WHC, where they were highest in bottom-ash, followed by roof-tile and lowest in scoria, regardless of whether modules were bare or planted (Figure 2). Planted modules used significantly more water than bare, with Cumulative ET 17-28\% being higher in planted modules depending on substrate. This was also true for Cumulative Retention, which was $12-31 \%$ higher in planted modules than bare. As a percentage of rainfall applied, planted bottom-ash modules retained the most rainfall $(42 \%)$ and bare scoria modules retained the least $(29 \%)$.
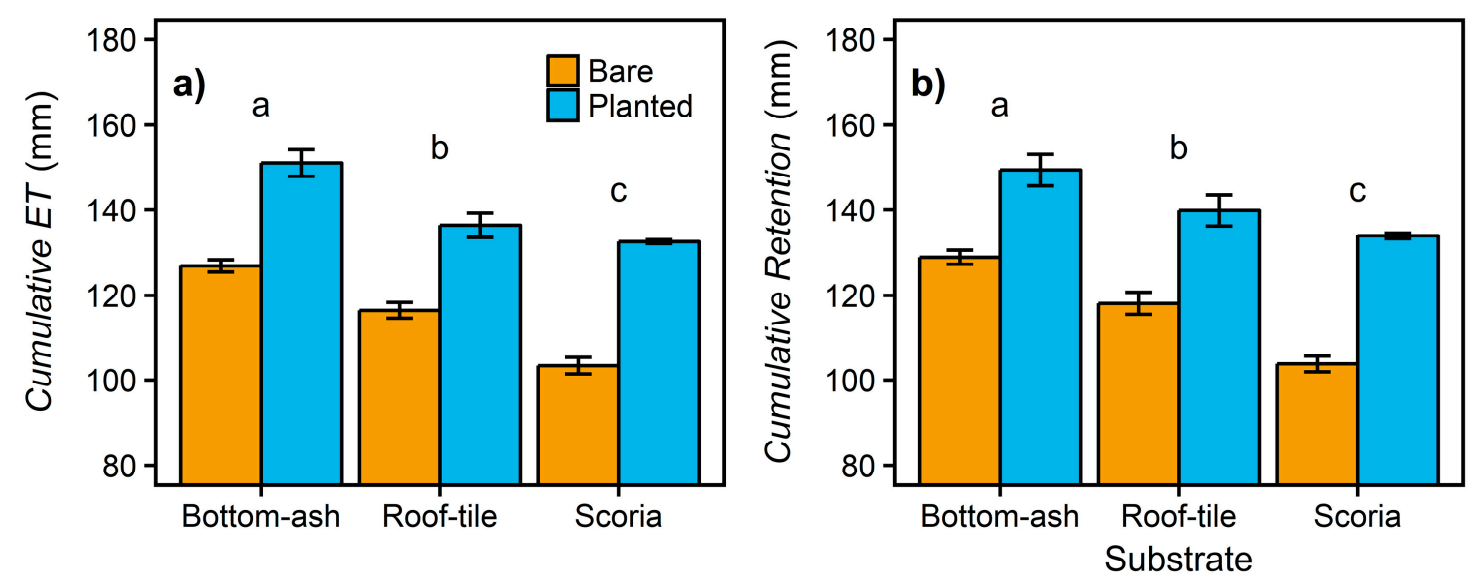

Figure 2. Cumulative evapotranspiration and retention for the experimental period. (a) Mean ( \pm standard error, $n=3$ ) Cumulative ET (evapotranspiration) and (b) mean ( \pm standard error, $n=3$ ) Cumulative Retention for each substrate and vegetation cover type. Different letters denote significant difference among substrates, rather than between vegetation cover types (both $p<0.001$ ). 


\subsection{Relationship between Available Storage and Rainfall Retention}

Models were initially fitted through each substrate and vegetation cover type for each event size, to describe the relationship between Avail. Stor (using all three methods; Avail. Stor ${ }_{\text {in situ }}$, Avail. Stor WHC $_{\text {W }}$ and Avail. Stor $\left.{ }_{P A W}\right)$ and Retention. However, the resulting slope of the regression lines did not differ significantly between substrate or vegetation cover types (all $p>0.05$ ). Therefore, for each method of calculating available storage, a single broken-stick (MARS) model was fitted to all of the substrates and vegetation cover types for each simulated rainfall event size.

Broken-stick (MARS) models described the relationships between available storage (Avail. Stor ${ }_{\text {in situ }}$, Avail. Stor ${ }_{W H C}$ and Avail. Stor ${ }_{P A W}$ ) and Retention well for events $>1.32 \mathrm{~mm}$ (all $p<0.001$;

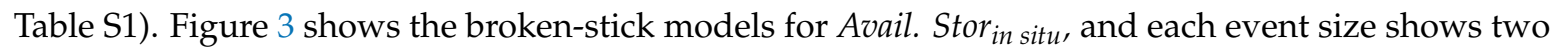
distinct regions: (i) an initial, steep and positive relationship where Retention was likely not limited by the event size, and (ii) a subsequent plateau where Retention no longer increased with available storage, most likely because Retention was limited by event size.
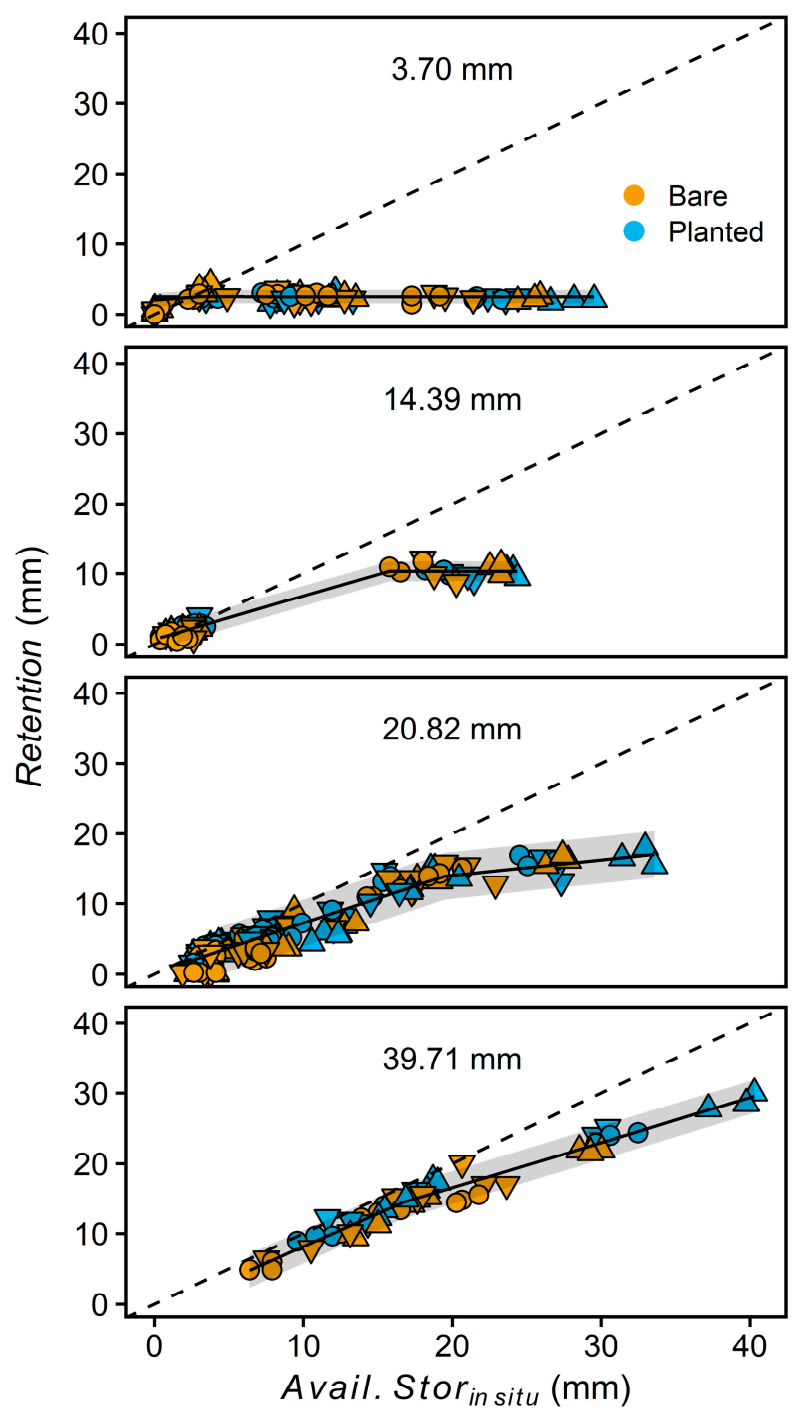

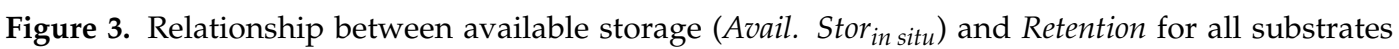
and vegetation cover types; facetted by rainfall event size. Symbol shape indicates substrate type: Bottom-ash (triangles), Roof-tile (inverted triangles) and Scoria (circles). Solid lines represent broken-stick (MARS) models fitted through all substrates and vegetation cover types for each simulated rainfall event size. Shaded ribbons indicate prediction intervals (95\%) for each model and dashed lines represent a 1:1 relationship. 
Event size had a major influence on Retention, independent of available storage (Figure 3). To determine the relationship between Avail. Stor (all three methods) and Retention independent of the effect of event size, we used the MARS model equations (Table S1) to exclude observations where Retention was limited by event size (represented by the plateau described above), rather than by Avail. Stor. Linear regression models were fitted for each method of calculating available storage and forced to avoid 'predicting' negative values of retention from available storage (Figure 4). The regression equations in Figure 4 show that retention was always less than the available storage (indicated by the 1:1 line), regardless of the method that was used to calculate Avail. Stor.

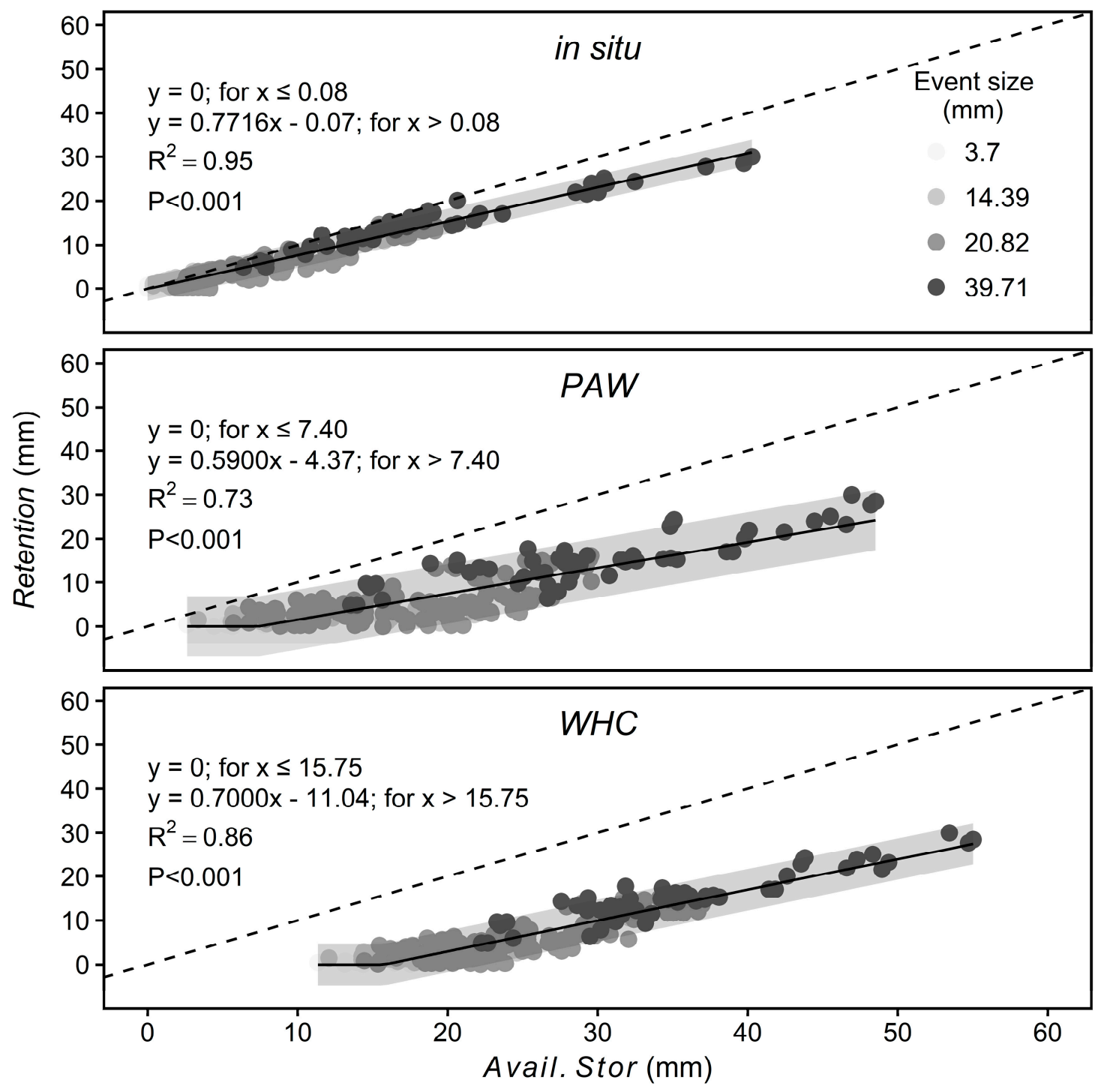

Figure 4. Relationship between available storage prior to rainfall (Avail. Stor) and Retention, not limited by rainfall event size. Points include all substrates and vegetation cover types and the three panels represent each method of calculating available storage: 'in situ', 'PAW' (plant available water) and ' $W H C$ ' (water-holding capacity). Symbol fill indicates event size in $\mathrm{mm}$. Lines represent linear models fitted through all points, forced equal to zero to avoid 'predicting' negative values for retention. Shaded ribbons indicate prediction intervals (95\%) for each linear model, $R^{2}$ and $p$-values are from fitted models and dashed lines represent a 1:1 relationship.

Interestingly, the directly determined maximum storage capacity that was used to calculate

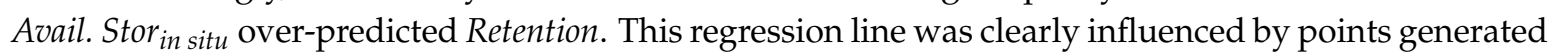


from larger event sizes and when the substrates were drier (i.e., at Avail. Stor in situ $_{\text {values }}>20 \mathrm{~mm}$ ). Table S2 shows predicted retention (by applying the equations in Figure 4) for a range of theoretical available storage values and the over-prediction errors show the extent to which assuming that retention simply equals available storage would over-predict retention. For example, retention would be over-predicted by a minimum of $50 \%$ for both WHC and PAW-derived calculations of available storage; and, by $\sim 23 \%$ for calculations derived from direct measures of module storage capacity

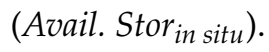

\section{Discussion}

\subsection{Effect of Substrate Physical Properties and Vegetation Cover on Rainfall Retention}

Cumulative ET, and therefore, Cumulative Retention were related to the physical properties of the three green roof substrates that were tested. Without vegetation cover, Cumulative ET was 34\% higher for the substrate with the greatest WHC (bottom-ash; 51.7\%), as compared with the scoria substrate $(W H C=45.9 \%)$. Clearly, this relatively small difference in storage capacity $(5.8 \%)$ had a disproportionally large effect on the amount of water, which could be evaporated from the bare modules. The roof-tile substrate had the lowest WHC (44\%), rather than the scoria substrate $(45.9 \%)$, and we found that differences in Cumulative ET between the three substrates were better related to their plant available water (PAW). Whilst WHC is often used to describe the maximum amount of stored water and the maximum substrate weight $[10,14]$, it does not necessarily represent water that can be extracted from the media, i.e., PAW [44]. Fassman and Simcock [14] and Stovin et al. [26] also found water retention of green roof substrates was better related to PAW than WHC. Therefore, despite not being generally described for green roof substrates [24], we suggest that $P A W$ should be routinely measured for all of the substrates to give a better indication of their storage capacity.

Overall, vegetation cover increased total water use through ET by at least $13 \%$ as compared with bare modules, which is consistent with other studies $[25,37,45,46]$. Vegetated roofs clearly have greater potential than bare roofs to retain rainfall by depleting stored water through transpiration between rain events [25]. New green roof substrates with greater $P A W$ should therefore be developed to maximise ET $[14,22]$ within the constraints that are imposed by weight-loadings and without decreasing air-filled porosity [22]. $P A W$ has been increased without increasing substrate weight or decreasing air-filled porosity through the use of water-retention additives, such as silicates and biochar $[18,22]$. By increasing $P A W$, additives may reduce the likelihood of runoff and increase the drying out of the substrate between rainfall events through an increased ET [18], such that the renewal of the rainfall retention capacity between events will be greater [25].

Rainfall retention as a proportion of rainfall applied in the simulation ranged from $38 \%$ to $42 \%$ for planted modules. While this is comparable to reported values $[16,47]$ it is low for a city such as Melbourne that has a warm, dry climate. Retention was likely lower as our simulation was not designed to replicate a realistic combination of rainfall and antecedent dry weather periods. Our simulation was skewed towards larger events as compared with the typical rainfall distribution pattern in Melbourne, such that we could focus on retention performance for significant events [26]. Further, rainfall retention in our experiment was likely lower than would be expected on an annual basis, as it mainly took place in late winter and early spring [48].

\subsection{Relationship between Substrate Water Storage and Rainfall Retention}

Substrate physical properties, such as $P A W$ and $W H C$, as determined from standard laboratory tests, are increasingly being used to predict the storage capacity of green roofs prior to construction $[16,24]$. However, in our three substrates using PAW or WHC to calculate storage over-estimated rainfall retention by $50-100 \%$. Fassman and Simcock [14] also suggested that using laboratory-derived measures of WHC of substrates will overestimate rainfall retention. Although Fassman and Simcock [14] found that rainfall retention was better predicted by substrate 
PAW than by WHC, we show that both of the measures over-estimated the rainfall retention capacity of our three substrates. The assumption to include the maximum drainage layer storage in our calculations may have exaggerated the degree by which calculated WHC and PAW over-estimated retention. It is possible that the drainage layer storage was not engaged to full capacity $(6.1 \mathrm{~mm})$; for example, if plant roots had penetrated the geotextile and filled the drainage voids. However, even where we excluded the drainage layer storage, we observed a significant over-estimation in storage for all three substrates. This suggests that assuming the rainfall retention capacity of a substrate is equal to its WHC or PAW may significantly over-estimate the modelled hydrologic benefits that are provided by green roofs.

It is important to note that the over-estimation of rainfall retention will be minimal for shallow-substrate systems (e.g., Sedum spp. carpet roofs with $\sim 30 \mathrm{~mm}$ of associated substrate) when compared with deeper substrates. Versini et al. [31] observed this when calibrating the SWMM model (version 5, United States Environmental Protection Agency, Washington, DC, USA), finding that the calibrated field capacity (WHC) of a $150 \mathrm{~mm}$ deep substrate was only $~ 50 \%$ of the laboratory-based value; yet, no such difference was found when the substrate was only $30 \mathrm{~mm}$ deep. It is also important to note that over-estimation of other processes, such as ET, may have a proportionally much more significant impact on modelling hydrological performance of green roofs [34]. For example, Stovin et al. [26] showed that their physical green roof model (based on a Sedum spp. carpet/shallow substrate configuration) would over-estimate rainfall retention to a much greater extent if $E T$ was over-estimated, as compared with the storage capacity of the substrate.

Several green roof models have avoided this potential source of error by determination of the maximum storage capacity of a roof via calibration of a physical model (e.g., [31,49]). Others assume that maximum storage is equivalent to the largest rainfall event observed not to generate runoff from a test rig or roof with a particular configuration (e.g., [26]). While this avoids over-estimation errors, it also limits the ability of these models to compare the rainfall retention of alternative substrates and installation configurations [16,24]. A key aim of our study was to determine whether it would be possible to model the retention performance of alternative substrates in the absence of runoff data, recognising that such data may not be available in practice. Adjusting standard laboratory-based measures of WHC or PAW to minimise the over-estimation of retention would be a useful starting point to improve existing models that assume maximum storage equal to the WHC or $P A W$ of the substrate [50]. We are not suggesting that green roof water balance models should change the fundamental assumption that runoff will only occur once substrate storage capacity is reached. Instead, we suggest that the maximum storage capacity of substrates, as determined from standard laboratory methods, should be adjusted down to be more realistic.

Interestingly, even the available storage that is calculated using the directly measured maximum storage capacity of the modules over-predicted retention, particularly when substrates were dry. Preferential flow pathways through the substrates, e.g., via plant roots (as observed in raingardens; e.g., Virahsawmy et al. [51]), shrinkage of plant roots or the organic substrate components and/or non-uniform wetting front most likely explain the occurrence of runoff prior to reaching available storage capacity $[14,28]$. However, it should also be noted that the relationship between available storage and retention was heavily influenced by the largest event size $(39.71 \mathrm{~mm})$ and the greatest calculated available storage values $(>20 \mathrm{~mm})$, which coincided with the longest antecedent dry weather period (eight days). In these circumstances (i.e., after significant drying out of the substrate), substrates may only partially re-wet and not achieve field capacity until all of the substrate components and roots reach full hydration [23]. Further, rainfall may have short-circuited the substrate due to shrinkage of plant roots and/or the substrate away from the edges of the test modules. However, even if we assume that the over-estimation of rainfall retention using measured storage capacity was the result of such an artefact, over-estimation from lab-based WHC and PAW was far greater. 


\section{Conclusions}

Substrate physical properties and vegetation cover can significantly influence green roof hydrological performance. While water holding capacity (WHC) is an important driver of rainfall retention, plant available water $(P A W)$ provided a better indication of water use and rainfall retention. However, both of these laboratory-based measures significantly over-estimated the real rainfall retention of a green roof for any given rainfall event, regardless of the substrate. Laboratory-based measures of $P A W$ and WHC should therefore be used with caution in green roof water balance models to avoid the over-estimation of retention performance. Improving the accuracy and reliability of modelled rainfall retention will ensure that green roofs for stormwater mitigation are appropriately designed to achieve policy outcomes.

Supplementary Materials: The following are available online at www.mdpi.com/2073-4441/9/12/920/s1, Figure S1: Photograph of experimental setup, Figure S2: Diagram of calculations, Table S1: MARS model equations for each method of calculating available storage and Table S2: Summary of over-prediction errors for each method of calculating available storage.

Acknowledgments: We thank Ruth Mitchell and Ross Payne for assistance developing the green roof modules and irrigation. Ruth also assisted with measurements, as did Beau Picking. Thanks to Nick Osborne and Sascha Andrusiak for technical assistance. This research was funded by Australian Research Council Linkage Grants (LP0990704 and LP130100731), supported by the Victorian Department of Sustainability and Environment, Melbourne Water, City of Melbourne, and The Committee for Melbourne. T.D. Fletcher was supported by an ARC Future Fellowship (FT100100144).

Author Contributions: Claire Farrell and Tim D. Fletcher conceived and designed the experiments; Claire Farrell performed the experiments; Christopher Szota, Claire Farrell, Carine Desbois and Tim D. Fletcher analyzed the data; all authors wrote the paper.

Conflicts of Interest: The authors declare no conflict of interest. The founding sponsors had no role in the design of the study; in the collection, analyses, or interpretation of data; in the writing of the manuscript, and in the decision to publish the results.

\section{References}

1. Grimmond, G.S.B.; Oke, T.R. Evapotranspiration rates in urban areas. In Impacts of Urban Growth on Surface Water and Groundwater Quality; IAHS (International Association of Hydrological Sciences) Publication: Birmingham, UK, 1999.

2. Walsh, C.J.; Roy, A.H.; Feminella, J.W.; Cottingham, P.D.; Groffman, P.M.; Morgan, R.P. The urban stream syndrome: Current knowledge and the search for a cure. J. N. Am. Benthol. Soc. 2005, 24, 706-723. [CrossRef]

3. Wenger, S.J.; Roy, A.H.; Jackson, C.R.; Bernhardt, E.S.; Carter, T.L.; Filoso, S.; Gibson, C.A.; Hession, W.C.; Kaushal, S.S.; Martí, E.; et al. Twenty-six key research questions in urban stream ecology: An assessment of the state of the science. J. N. Am. Benthol. Soc. 2009, 28, 1080-1098. [CrossRef]

4. King, R.S.; Baker, M.E.; Kazyak, P.F.; Weller, D.E. How novel is too novel? Stream community thresholds at exceptionally low levels of catchment urbanization. Ecol. Appl. 2011, 21, 1659-1678. [CrossRef] [PubMed]

5. Burns, M.J.; Fletcher, T.D.; Walsh, C.J.; Ladson, A.R.; Hatt, B.E. Hydrologic shortcomings of conventional urban stormwater management and opportunities for reform. Landsc. Urban Plan. 2012, 105, $230-240$. [CrossRef]

6. Villarreal, E.L.; Bengtsson, L. Response of a sedum green-roof to individual rain events. Ecol. Eng. 2005, 25, 1-7. [CrossRef]

7. Carter, T.L.; Jackson, C.R. Vegetated roofs for stormwater management at multiple spatial scales. Landsc. Urban Plan. 2007, 80, 84-94. [CrossRef]

8. Czemiel Berndtsson, J. Green roof performance towards management of runoff water quantity and quality: A review. Ecol. Eng. 2010, 36, 351-360. [CrossRef]

9. Carter, T.; Fowler, L. Establishing green roof infrastructure through environmental policy instruments. Environ. Manag. 2008, 42, 151-164. [CrossRef] [PubMed]

10. Ampim, P.A.Y.; Sloan, J.J.; Cabrera, R.I.; Harp, D.A.; Jaber, F.H. Green roof growing substrates: Types, ingredients, composition and properties. J. Environ. Hortic. 2010, 28, 244-252. 
11. Getter, K.L.; Rowe, D.B. The role of extensive green roofs in sustainable development. Hortscience 2006, 41, 1276-1285.

12. FLL (Forschungsgesellschaft Landschaftsentwicklung Landschaftsbau). Guidelines for the Planning, Construction and Maintenance of Green Roofing; Forschungsgesellschaft Landschaftsentwicklung Landschaftsbau: Bonn, Germany, 2008.

13. Molineux, C.J.; Fentiman, C.H.; Gange, A.C. Characterising alternative recycled waste materials for use as green roof growing media in the UK. Ecol. Eng. 2009, 35, 1507-1513. [CrossRef]

14. Fassman, E.; Simcock, R. Moisture measurements as performance criteria for extensive living roof substrates. J. Environ. Eng. 2012, 138, 841-851. [CrossRef]

15. Young, T.; Cameron, D.D.; Sorrill, J.; Edwards, T.; Phoenix, G.K. Importance of different components of green roof substrate on plant growth and physiological performance. Urban Urban Green. 2014, 13, 507-516. [CrossRef]

16. Li, Y.; Babcock, R.W., Jr. Green roof hydrologic performance and modeling: A review. Water Sci. Technol. 2014, 69, 727-738. [CrossRef] [PubMed]

17. Oberndorfer, E.; Lundholm, J.; Bass, B.; Coffman, R.R.; Doshi, H.; Dunnett, N.; Gaffin, S.; Kohler, M.; Liu, K.K.Y.; Rowe, B. Green roofs as urban ecosystems: Ecological structures, functions, and services. Bioscience 2007, 57, 823-833. [CrossRef]

18. Cao, C.T.N.; Farrell, C.; Kristiansen, P.E.; Rayner, J.P. Biochar makes green roof substrates lighter and improves water supply to plants. Ecol. Eng. 2014, 71, 368-374. [CrossRef]

19. Stovin, V.; Vesuviano, G.; Kasmin, H. The hydrological performance of a green roof test bed under UK climatic conditions. J. Hydrol. 2012, 414, 148-161. [CrossRef]

20. Williams, N.S.G.; Rayner, J.P.; Raynor, K.J. Green roofs for a wide brown land: Opportunities and barriers for rooftop greening in australia. Urban For. Urban Green. 2010, 9, 245-251. [CrossRef]

21. Harper, G.E.; Limmer, M.A.; Showalter, W.E.; Burken, J.G. Nine-month evaluation of runoff quality and quantity from an experiential green roof in missouri, USA. Ecol. Eng. 2015, 78, 127-133. [CrossRef]

22. Farrell, C.; Ang, X.Q.; Rayner, J.P. Water-retention additives increase plant available water in green roof substrates. Ecol. Eng. 2013, 52, 112-118. [CrossRef]

23. Berretta, C.; Poë, S.; Stovin, V. Moisture content behaviour in extensive green roofs during dry periods: The influence of vegetation and substrate characteristics. J. Hydrol. 2014, 511, 374-386. [CrossRef]

24. Carson, T.; Keeley, M.; Marasco, D.E.; McGillis, W.; Culligan, P. Assessing methods for predicting green roof rainfall capture: A comparison between full-scale observations and four hydrologic models. Urban Water J. 2017, 14, 589-603. [CrossRef]

25. Poë, S.; Stovin, V.; Berretta, C. Parameters influencing the regeneration of a green roof's retention capacity via evapotranspiration. J. Hydrol. 2015, 523, 356-367. [CrossRef]

26. Stovin, V.; Poë, S.; Berretta, C. A modelling study of long term green roof retention performance. J. Environ. Manag. 2013, 131, 206-215. [CrossRef] [PubMed]

27. Kasmin, H.; Stovin, V.R.; Hathway, E.A. Towards a generic rainfall-runoff model for green roofs. Water Sci. Technol. 2010, 62, 898-905. [CrossRef] [PubMed]

28. She, N.; Pang, J. Physically based green roof model. J. Hydrol. Eng. 2010, 15, 458-464. [CrossRef]

29. Hilten, R.N.; Lawrence, T.M.; Tollner, E.W. Modeling stormwater runoff from green roofs with hydrus-1d. J. Hydrol. 2008, 358, 288-293. [CrossRef]

30. Szota, C.; Farrell, C.; Williams, N.S.G.; Arndt, S.K.; Fletcher, T.D. Drought-avoiding plants with low water use can achieve high rainfall retention without jeopardising survival on green roofs. Sci. Total Environ. 2017, 603-604, 340-351. [CrossRef] [PubMed]

31. Versini, P.-A.; Ramier, D.; Berthier, E.; De Gouvello, B. Assessment of the hydrological impacts of green roof: From building scale to basin scale. J. Hydrol. 2015, 524, 562-575. [CrossRef]

32. Carson, T.B.; Marasco, D.E.; Culligan, P.J.; McGillis, W.R. Hydrological performance of extensive green roofs in new york city: Observations and multi-year modeling of three full-scale systems. Environ. Res. Lett. 2013, 8, 024036. [CrossRef]

33. Nawaz, R.; McDonald, A.; Postoyko, S. Hydrological performance of a full-scale extensive green roof located in a temperate climate. Ecol. Eng. 2015, 82, 66-80. [CrossRef]

34. Locatelli, L.; Mark, O.; Mikkelsen, P.S.; Arnbjerg-Nielsen, K.; Jensen, M.B.; Binning, P.J. Modelling of green roof hydrological performance for urban drainage applications. J. Hydrol. 2014, 519, 3237-3248. [CrossRef] 
35. Allen, R.G.; Pereira, L.S.; Raes, D.; Smith, M. Crop Evapotranspiration: Guidelines for Computing Crop Water Requirements; Food and Agriculture Organisation of the United Nations: Rome, Italy, 1998.

36. Jeffrey, S.J.; Carter, J.O.; Moodie, K.B.; Beswick, A.R. Using spatial interpolation to construct a comprehensive archive of australian climate data. Environ. Model. Softw. 2001, 16, 309-330. [CrossRef]

37. Farrell, C.; Mitchell, R.E.; Szota, C.; Rayner, J.P.; Williams, N.S.G. Green roofs for hot and dry climates: Interacting effects of plant water use, succulence and substrate. Ecol. Eng. 2012, 49, 270-276. [CrossRef]

38. Standards Australia. Australian Standard as 3743: Potting Mixes; Standards Australia International Ltd.: Sydney, Australia, 2003.

39. Greacen, E.L.; Walker, G.R.; Cook, P.G. Procedure for Filter Paper Method of Measuring Soil Water Suction; Commonwealth Scientific and Industrial Research Organisation: Melbourne, Australia, 1989.

40. Jonasson, S. The point intercept method for non-destructive estimation of biomass. Phytocoenologia 1983, 11, 385-388. [CrossRef]

41. R Core Team. R: A Language and Environment for Statistical Computing; R Foundation for Statistical Computing: Vienna, Austria, 2014. Available online: http:/ / www.R-project.Org/ (accessed on 24 November 2017).

42. Friedman, J.H. Multivariate adaptive regression splines. Ann. Stat. 1991, 19, 1-67. [CrossRef]

43. Milborrow, S. Earth: Multivariate Adaptive Regression Splines (Derived from mda:Mars by Trevor Hastie and Rob Tibshirani. Uses Alan Miller's Fortran Utilities with Thomas Lumley's Leaps Wrapper). R Package Version 4.2.0. 2015. Available online: http://cran.r-project.org/web/packages/earth/ (accessed on 24 November 2017).

44. Nguyen, T.-T.; Joyce, D.C.; Dinh, S.-Q. Effects of artificial amendments in potting media on Orthosiphon aristatus growth and development. Sci. Hortic. 2009, 123, 129-136. [CrossRef]

45. VanWoert, N.D.; Rowe, D.B.; Andresen, J.A.; Rugh, C.L.; Fernandez, R.T.; Xiao, L. Green roof stormwater retention. J. Environ. Qual. 2005, 34, 1036-1044. [CrossRef] [PubMed]

46. Voyde, E.; Fassman, E.; Simcock, R.; Wells, J. Quantifying evapotranspiration rates for new zealand green roofs. J. Hydrol. Eng. 2010, 15, 395-403. [CrossRef]

47. Cipolla, S.S.; Maglionico, M.; Stojkov, I. A long-term hydrological modelling of an extensive green roof by means of swmm. Ecol. Eng. 2016, 95, 876-887. [CrossRef]

48. Elliott, R.M.; Gibson, R.A.; Carson, T.B.; Marasco, D.E.; Culligan, P.J.; McGillis, W.R. Green roof seasonal variation: Comparison of the hydrologic behavior of a thick and a thin extensive system in new york city. Environ. Res. Lett. 2016, 11, 074020. [CrossRef]

49. Yang, W.-Y.; Li, D.; Sun, T.; Ni, G.-H. Saturation-excess and infiltration-excess runoff on green roofs. Ecol. Eng. 2015, 74, 327-336. [CrossRef]

50. Vanuytrecht, E.; Van Mechelen, C.; Van Meerbeek, K.; Willems, P.; Hermy, M.; Raes, D. Runoff and vegetation stress of green roofs under different climate change scenarios. Landsc. Urban Plan. 2014, 122, 68-77. [CrossRef]

51. Virahsawmy, H.K.; Stewardson, M.J.; Vietz, G.; Fletcher, T.D. Factors that affect the hydraulic performance of raingardens: Implications for design and maintenance. Water Sci. Technol. 2014, 69, 982-988. [CrossRef] [PubMed]

(C) 2017 by the authors. Licensee MDPI, Basel, Switzerland. This article is an open access article distributed under the terms and conditions of the Creative Commons Attribution (CC BY) license (http://creativecommons.org/licenses/by/4.0/). 